\title{
PERTIMBANGAN HAKIM TERHADAP DISPENSASI NIKAH DI BAWAH UMUR (STUDI KASUS PENGADILAN AGAMA PARIGI)
}

\author{
Andini Asmarini \\ Dosen Fakultas Syariah UIN Datokarama Palu \\ Email: andini9403@gmail.com
}

\begin{abstract}
This study examines the judge's considerations in resolving marriage dispensation cases at the Parigi Religious Court. This research includes field research with qualitative methods. Data was collected through documentation studies, interviews, and observations. Data analysis techniques used are data reduction, data presentation, data interpretation, and drawing conclusions. The background of this research is Law No. 16 of 2019 Article 7 paragraph 1 regarding the minimum age of marriage, which is 19 years for men and women, as well as paragraphs 2 \& 3 regarding the granting of marriage dispensation with very urgent reasons. The description in this journal departs from the factors that form the background of the application for a marriage dispensation and how judges consider in resolving a marriage dispensation case at the Parigi Religious Court. The results showed that the background of the application for marriage dispensation at the Parigi Religious Court was due to pregnancy outside of marriage, arranged marriages, and reasons to avoid adultery. The considerations made by the judge are through the principle of expediency, the necessity to refuse harm, the interests of the child and baby in the womb, and the legal compliance of the family. From the conclusions obtained, it is recommended that the government and community organizations intensively conduct speeches and counseling about the dangers of early marriage in the community, as well as increase parental and family supervision of the association and development of children.
\end{abstract}

Keywords: Dispensation, Judge's Consideration, Early Marriage

\begin{abstract}
Abstrak
Penelitian ini mengkaji tentang pertimbangan hakim dalam penyelesaian perkara dispensasi nikah di Pengadilan Agama Parigi. Penelitian ini termasuk penelitian lapangan dengan metode kualitatif. Pengumpulan data dilakukan melalui studi dokumentasi, wawancara, dan observasi. Teknik analisis data yang digunakan adalah reduksi data, penyajian data, penafsiran data, dan penarikan kesimpulan. Latar belakang penelitian ini adalah Undang-Undang No 16 Tahun 2019 Pasal 7 ayat 1 mengenai umur minimal pernikahan yaitu 19 tahun bagi pria dan wanita, serta ayat 2 \& 3 mengenai pemberian dispensasi nikah dengan alasan sangat mendesak. Uraian dalam jurnal ini berangkat dari faktor-faktor yang menjadi latar belakang permohonan
\end{abstract}


dispensasi nikah dan bagaimana pertimbangan hakim dalam menyelesaikan perkara dispensasi nikah di Pengadilan Agama Parigi. Hasil penelitian menunjukkan bahwa latar belakang permohonan dispensasi nikah di Pengadilan Agama Parigi akibat kondisi hamil di luar nikah, perjodohan, dan alasan menghindari zina. Adapun pertimbangan yang dilakukan hakim yaitu melalui asas kemanfaatan, keharusan untuk menolak mudharat, kepentingan anak dan bayi dalam kandungan, serta kepatuhan hukum pihak keluarga. Dari kesimpulan yang diperoleh, disarankan agar pemerintah serta organisasi kemasyarakatan gencar melakukan orasi dan penyuluhan tentang bahaya menikah dini di tengah masyarakat, serta meningkatkan pengawasan orang tua dan keluarga terhadap pergaulan dan perkembangan anak.

Kata Kunci: Dispensasi, Pertimbangan Hakim, Pernikahan Dini

\section{A. Pendahuluan}

Pernikahan merupakan suatu hal yang sangat penting dalam kehidupan manusia. Melalui pernikahan, hubungan rumah tangga dapat dibina dan dijalankan sesuai dengan norma agama dan tata kehidupan bermasyarakat. Dalam rumah tangga berkumpul dua insan yang berlainan jenis (suami istri), mereka saling berhubungan agar mendapatkan keturunan sebagai penerus generasi. Insan-insan yang berada dalam rumah tangga itulah yang disebut keluarga. ${ }^{1}$ Keluarga, merupakan unit terkecil dari suatu bangsa, keluarga yang dicita-citakan dalam ikatan pernikahan yang sah adalah keluarga sejahtera dan bahagia yang selalu mendapat ridha Allah swt. $^{2}$

Tujuan pernikahan adalah untuk mewujudkan rumah tangga bahagia dan sejahtera dengan mewujudkan suasana rukun dan damai dalam rumah tangga yang selalu mendapat taufik dan hidayah dari Tuhan Yang Mahakuasa. Agar hal ini dapat terlaksana, maka kematangan calon mempelai sangat diharapkan, kematangan dimaksud di sini adalah kematangan umur pernikahan, kematangan dalam berpikir dan bertindak sehingga tujuan

1 Yusuf, Psikologi Perkembangan Anak dan Remaja (Bandung: PT Remaja Rosdakarya Offset, 2004), 138.

${ }^{2}$ Abdul Manan, Aneka Masalah Hukum Perdata Islam di Indonesia, (Jakarta; Kencana, 2014), 2. 
pernikahan tersebut dapat terlaksana dengan baik. Sebagaimana telah dikemukakan dalam Undang-undang Perkawinan membatasi umur untuk melaksanakan pernikahan yaitu 19 tahun bagi pria dan wanita. $^{3}$ Penyimpangan dari batas umur minimal pernikahan ini harus melalui berbagai pertimbangan yang matang, setelah itu baru pernikahan dapat dilaksanakan. Pihak-pihak berkepentingan dilarang keras membantu melaksanakan pernikahan di bawah umur. Pelanggaran terhadap ketentuan yang telah ditetapkan itu dapat dikenakan sanksi dengan peraturan yang berlaku. ${ }^{4}$

Dalam Undang-Undang Perkawinan Nomor 16 Tahun 2019 tentang Perkawinan Pasal 7 ayat (2) dijelaskan bahwa jika terjadi penyimpangan terhadap ketentuan yang disebutkan dalam Pasal sebelumnya, maka pihak keluarga maupun calon pasangan dapat meminta dispensasi kepada Pengadilan yang ditunjuk oleh kedua orang tua pihak pria maupun pihak wanita. ${ }^{5}$

Terdapat beberapa resiko yang umum terjadi pada pasangan di bawah umur. Di antaranya kematangan organ reproduksi yang belum sempurna bagi wanita, ${ }^{6}$ mental dan psikologis yang belum stabil, kesiapan sosial dan finansial yang belum memadai, serta pengetahuan berkeluarga dan mengurus anak yang belum dimiliki oleh calon pasangan di bawah umur. Maka dari itu, dalam memberikan dispensasi nikah bagi pasangan muda, halhal tersebut semestinya menjadi sangat dipertimbangkan terlebih dahulu. Namun hingga saat ini masih banyak pasangan yang memilih menikah di bawah umur dan di antaranya memperoleh izin berupa dispensasi nikah dari Pengadilan Agama. Terbukti, data perkara dispensasi nikah di Pengadilan

${ }^{3}$ Lihat Undang-undang Perkawinan Nomor 16 Tahun 2019

4 Ibid.,

5 Ibid.,

6 Perwakilan Badan Kependudukan Dan Keluarga Berencana Nasional (BKKBN) Provinsi Sulawesi Tengah, Seri GenRe: Menyiapkan Generasi Emas, 55. 
Agama Parigi tercatat sebanyak 11 perkara pada 2016 dan mengalami peningkatan pada tahun 2017 yakni sebanyak 24 perkara. $^{7}$

\section{B. Pembahasan}

\section{Dispensasi Nikah dan Regulasinya}

Dalam penjelasan umum Undang-undang Nomor 48 Tahun 2009 tentang Kekuasaan Kehakiman dikatakan Undang-undang Dasar Negara Republik Indonesia Tahun 1945 menegaskan bahwa Indonesia adalah negara hukum. ${ }^{8}$ Sejalan dengan ketentuan tersebut maka salah satu prinsip penting negara hukum adalah adanya jaminan penyelenggaraan kekuasaan kehakiman yang merdeka, bebas dari pengaruh kekuasaan lainnya untuk menyelenggarakan peradilan guna menegakkan hukum dan keadilan. ${ }^{9}$

Selanjutnya dalam Undang-undang Dasar 1945 Pasal 24 ayat (2), dijelaskan bahwa, pelaksanaan dari penyelenggaraan kekuasaan kehakiman dilakukan oleh sebuah Mahkamah Agung dan badan peradilan yang berada di bawahnya, yaitu dalam Peradilan Umum, Peradilan Agama, Peradilan Militer, dan Peradilan Tata Usaha Negara serta oleh sebuah Mahkamah Konstitusi.10

Kekuasaan Kehakiman memiliki kekuasaan yang sangat besar dalam menentukan putusan apa yang akan diambil oleh seorang hakim dalam mengadili suatu perkara yang dihadapkan kepadanya. Undang-undang Nomor 48 Tahun 2009 tentang Kekuasaan Kehakiman menjelaskan bahwa setiap hakim sebelum memutuskan wajib menyampaikan pertimbangan atau pendapat tertulis terhadap perkara yang sedang diperiksa. Hal ini merupakan bagian yang tidak terpisahkan dari sebuah putusan yang dihasilkan dari lembaga peradilan. ${ }^{11}$

7 Andini Puspita Sari, Panitera Muda Pengadilan Agama Parigi, "Wawancara" (9 Februari 2018).

${ }^{8}$ Anshary, Hukum Perkawinan di Indonesia (Yogyakarta: Pustaka Pelajar, 2015), 12.

9 Zaeni Asyhadie dan Arief Rahman, Pengantar Ilmu Hukum (Jakarta: PT Raja Grafindo Persada, 2014), 199.

10 Lihat Undang-undang Dasar Republik Indonesia, Pasal 24 ayat (2)

11 Undang-undang Nomor 48 Tahun 2009 Tentang Kekuasaan Kehakiman Pasal 14. 
Peradilan Agama sebagai salah satu pelaksana kekuasaan kehakiman mempunyai tugas pokok untuk menerima, memeriksa dan mengadili serta menyelesaikan setiap perkara yang diajukan kepadanya guna menegakkan hukum dan keadilan berdasarkan Pancasila demi terselenggaranya negara hukum Republik Indonesia. ${ }^{12}$

Dispensasi nikah adalah keringanan yang diberikan Undang-undang melalui Pengadilan Agama terhadap anak dibawah umur agar dapat melangsungkan pernikahan ataupun pernikahan. ${ }^{13}$ Perkara dispensasi nikah termasuk perkara permohonan yang hasilnya berupa penetapan. Untuk mengabulkan maupun menolak permasalahan tersebut hakim memerlukan pertimbangan yang matang agar putusan tersebut mengandung kepastian hukum, keadilan dan kemanfaatan bagi masyarakat. Pertimbangan adalah suatu tahapan dimana majelis hakim mempertimbangkan fakta-fakta yang terungkap selama persidangan berlangsung. Sehingga didalam persidangan hakim harus menggali fakta-fakta yang sebenarnya yang terjadi pada para pemohon. Hasil pertimbangan itu merupakan hukum karena mempunyai kekuatan mengikat sebagai hukum karena dituangkan dalam bentuk putusan. ${ }^{14}$

Pengadilan agama bukan saja di tuntut untuk memantapkan diri sebagai lembaga kekuasaan kehakiman yang harus menerapkan hukum acara dengan baik dan benar tetapi juga sebagai lembaga sosial yang menyelesaikan masalah sengketa keluarga dengan cara-cara yang tidak menimbulkan kerusakan rohani dan sosial kepada anggota keluarga pencari keadilan. Putusan hakim yang baik ialah yang memenuhi tiga unsur aspek secara berimbang, yaitu memberikan kepastian hukum, rasa keadilan, dan manfaat bagi para pihak dan masyarakat. ${ }^{15}$

12 H.A. Mukti Arto, Praktek Perkara Perdata Pada Pengadilan Agama (Yogyakarta: Pustaka Pelajar, 2007), 29.

13 Lihat UU Perkawinan Nomor 16 Tahun 2019

14 Sudikno Mertokusumo, Penemuan Hukum (Yogyakarta: Liberty, 2009), 38.

15 H.A. Mukti Arto, Praktek Perkara Perdata Pada Pengadilan Agama, 35. 
Hakim sebagai penegak hukum dan keadilan wajib menggali, mengikuti dan memahami nilai-nilai hukum yang hidup dalam masyarakat. Dan hakim memperhatikan sungguh-sungguh nilai-nilai hukum yang hidup dalam masyarakat, sehingga putusannya sesuai dengan rasa keadilan. Selain itu hakim harus mampu melakukan penemuan hukum agar dapat memberikan pelayanan hukum dan keadilan terhadap kasus-kasus yang terus berkembang. ${ }^{16} \mathrm{Hal}$ ini diatur di dalam Pasal 5 ayat (1) Undang-undang Nomor 48 Tahun 2009 tentang Kekuasaan Kehakiman yang menyatakan bahwa: "Hakim dan hakim konstitus wajib menggali, mengikuti, dan memahami nilai-nilai hukum dan rasa keadilan yang hidup dalam masyarakat". ${ }^{17}$ Dijelaskan pula bahwa setiap hakim sebelum memutuskan wajib menyampaikan pertimbangan atau pendapat tertulis terhadap perkara yang sedang diperiksa. Hal ini merupakan bagian yang tidak terpisahkan dari sebuah putusan yang dihasilkan dari lembaga peradilan. ${ }^{18}$

Dispensasi nikah adalah keringanan yang diberikan Undang-undang melalui Pengadilan Agama terhadap anak dibawah umur agar dapat melangsungkan pernikahan ataupun pernikahan. Perkara dispensasi nikah termasuk perkara permohonan yang hasilnya berupa penetapan. Untuk mengabulkan maupun menolak permasalahan tersebut hakim memerlukan pertimbangan yang matang agar putusan tersebut mengandung kepastian hukum, keadilan dan kemanfaatan bagi masyarakat. Pertimbangan adalah suatu tahapan dimana majelis hakim mempertimbangkan fakta-fakta yang terungkap selama persidangan berlangsung. Sehingga didalam persidangan hakim harus menggali fakta-fakta yang sebenarnya yang terjadi pada para pemohon. Hasil pertimbangan itu merupakan hukum karena mempunyai

\footnotetext{
${ }^{16}$ H.A. Mukti Arto, Praktek Perkara Perdata Pada Pengadilan Agama, 35.

17 Undang-undang Nomor 48 Tahun 2009 tentang Kekuasaan Kehakiman.

18 Undang-undang Nomor 48 Tahun 2009 Tentang Kekuasaan Kehakiman.
} 
kekuatan mengikat sebagai hukum karena dituangkan dalam bentuk putusan. ${ }^{19}$

Pengadilan agama bukan saja di tuntut untuk memantapkan diri sebagai lembaga kekuasaan kehakiman yang harus menerapkan hukum acara dengan baik dan benar tetapi juga sebagai lembaga sosial yang menyelesaikan masalah sengketa keluarga dengan cara-cara yang tidak menimbulkan kerusakan rohani dan sosial kepada anggota keluarga pencari keadilan. Putusan hakim yang baik ialah yang memenuhi tiga unsur aspek secara berimbang, yaitu memberikan kepastian hukum, rasa keadilan, dan manfaat bagi para pihak dan masyarakat. ${ }^{20}$

Undang-undang Perkawinan ini telah menampung di dalamnya unsurunsur dan ketentuan-ketentuan hukum agamanya dan kepercayaannya itu dari yang bersangkutan. Undang-undang ini menganut prinsip bahwa calon suami istri itu harus telah matang jiwa raganya untuk dapat melangsungkan pernikahan, agar supaya dapat mewujudkan tujuan pernikahan secara baik tanpa berakhir pada perceraian dan mendapat keturunan yang baik dan sehat. Untuk itu harus dicegah adanya pernikahan antara calon suami istri yang masih dibawah umur. ${ }^{21}$

Sebelum melangsungkan pernikahan, maka calon mempelai harus memenuhi syarat-syarat yang ditentukan oleh Undang-undang Perkawinan yang menyatakan bahwa: "Perkawinan hanya diizinkan apabila pria dan wanita sudah mencapai umur 19 (sembilan belas) tahun"22

Penentuan batas umur untuk melangsungkan pernikahan sangatlah penting sekali, karena suatu pernikahan disamping menghendaki kematangan biologis juga kematangan psikologis. Maka dalam penjelasan umum Undang-undang Perkawinan dinyatakan, bahwa calon suami istri itu

${ }^{19}$ Sudikno Mertokusumo, Penemuan Hukum (Yogyakarta: Liberty, 2009), 38.

${ }^{20}$ H.A. Mukti Arto, Praktek Perkara Perdata Pada Pengadilan Agama, 35.

${ }^{21}$ Ibid., 8.

22 Undang-Undang Republik Indonesia Nomor 16 Tahun 2019 Tentang Perubahan Atas Undang-Undang Nomor 1 Tahun 1974. 
harus telah matang jiwa raganya untuk dapat melangsungkan pernikahan agar supaya dapat mewujudkannya secara baik tanpa berakhir pada perceraian dan mendapat keturunan yang baik dan sehat. Untuk itu harus dicegah adanya pernikahan antara calon suami istri yang masih di bawah umur.

Apabila belum mencapai umur tersebut, untuk melangsungkan pernikahan diperlukan suatu dispensasi dari Pengadilan atau Pejabat lain yang ditunjuk oleh kedua orang tua pihak pria maupun wanita. Hal ini diatur dalam Pasal 7 ayat (2) Undang-undang Perkawinan Nomor 1 Tahun 1974: "Dalam hal penyimpangan terhadap ayat (1) pasal ini dapat meminta dispensasi kepada Pengadilan atau pejabat yang ditunjuk oleh kedua orang tua pihak pria maupun wanita". ${ }^{23}$

Dispensasi nikah adalah suatu kelonggaran atau keringanan yang diberikan oleh pengadilan kepada calon suami istri yang belum memenuhi syarat materiil dalam pernikahan yaitu belum mencapai batas umur minimal 19 tahun untuk dapat melangsungkan pernikahan. Undang-undang Perkawinan ini bertujuan untuk mencegah terjadinya pernikahan anak-anak, agar pemuda pemudi yang akan menjadi suami istri benar-benar telah masak jiwa raganya dalam membentuk keluarga/rumah tangga yang bahagia dan kekal. Begitu pula dimaksudkan untuk dapat mencegah terjadinya perceraian dini dan agar dapat membenihkan keturunan yang baik dan sehat, serta tidak berakibat laju kelahiran yang lebih tinggi sehingga mempercepat pertambahan penduduk. ${ }^{24}$ Selain itu, bahwa batas umur yang lebih rendah bagi wanita untuk menikah mengakibatkan laju kelahiran yang lebih tinggi dan berakibat pula pada kematian ibu hamil yang relatif tinggi, pengaruh buruk lainnya adalah kesehatan reproduksi wanita jadi terganggu. ${ }^{25}$

\footnotetext{
23 Undang-Undang Perkawinan Nomor 1 Tahun 1974, pasal 7.

${ }^{24}$ Hilman Hadikusuma, Hukum Perkawinan Indonesia (Bandung: CV. Mandar Maju, 2007), 48.

25 Perwakilan Badan Kependudukan Dan Keluarga Berencana Nasional (BKKBN) Provinsi Sulawesi Tengah, Seri GenRe : Menyiapkan Generasi Emas, 51.
} 
Dalam Undang-undang Nomor 1 Tahun 1974 terkandung beberapa asas-asas untuk menjamin cita-cita luhur pernikahan, yaitu asas sukarela, partisipasi keluarga, poligami dibatasi secara ketat, dan kematangan fisik dan mental calon mempelai. Asas kematangan fisik dan mental calon mempelai merupakan manifestasi dari ketentuan batas minimal usia dapat melangsungkan pernikahan. ${ }^{26}$

\section{Dispensasi Nikah Menurut Kompilasi Hukum Islam}

Kompilasi Hukum Islam di Indonesia merupakan ijma" para ulama Indonesia. Dan pada dasarnya apa yang termuat dalam Kompilasi Hukum Islam yang berhubungan dengan pernikahan semuanya telah dimuat dalam Undang-undang Nomor 1 Tahun 1974 tentang Perkawinan dan Undangundang No 16 Tahun 2019 tentang perubahan atas Undang-undang Nomor 1 Tahun 1974. Peraturan Pemerintahan Nomor 9 Tahun 1975 tentang Pelaksanaan Undang-undang. Hanya saja dalam Kompilasi Hukum Islam muatannya lebih terperinci, larangan dipertegas dan menambah beberapa point sebagai aplikasi dari peraturan perundang-undangan yang telah ada. ${ }^{27}$

Dispensasi dalam kamus besar bahasa Indonesia adalah pengecualian dari aturan umum untuk keadaan yang khusus, pembebasan dari suatu kewajiban atau larangan. Atau dispensasi dalam pengertian lain adalah izin pembebasan dari kewajiban, kelonggaran waktu atau keringanan dalam hal kasus dari ketentuan undang-undang. Dapat disimpulkan bahwa dispensasi nikah adalah keringanan yang diberikan Undang-undang melalui Pengadilan Agama terhadap anak dibawah umur agar dapat melangsungkan penikahan. ${ }^{28}$

26 Undang-Undang Perkawinan Nomor 1 Tahun 1974, pasal 6 ayat (2): "Untuk melangsungkan perkawinan seorang yang belum mencapai umur 21 (dua puluh satu) tahun harus mendapat izin kedua orang tua" dan pasal 7 ayat (1) "perkawinan hanya diizinkan bila pihak pria mencapai umur 19 (sembilan belas) tahun dan pihak wanita sudah mencapai usia 16 (enak belas) tahun.

${ }^{27}$ Abdul Manan, Aneka Masalah Hukum Perdata Islam Di Indonesia (Jakarta: Kecana, 2006), 27.

28 Ibid., 
Kompilasi Hukum Islam ketika membahas rukun pernikahan berbeda dengan Undang-undang Nomor 1 Tahun 1974, perbedaan itu terletak didalam Undang-undang Perkawinan tidak dijelaskan secara khusus mengenai rukun pernikahan tetapi di dalam Kompilasi Hukum Islam dijelaskan. Dan dalam hal rukun Kompilasi Hukum Islam mengikuti fiqh, hal ini dimuat dalam pasal 14 Kompilasi Hukum Islam. ${ }^{29}$

Kendatipun Kompilasi Hukum Islam menjelaskan lima rukun pernikahan sebagaimana fiqh, ternyata di dalam uraian persyaratan pernikahan, Kompilasi Hukum Islam mengikuti Undang-undang Perkawinan yang melihat syarat hanya berkenaan dengan persetujuan kedua calon mempelai dan batasan umur. Sebagaimana dijelaskan didalam pasal 15 ayat (1) dan (2) mengenai batasan umur dan batas dewasa: (1) Untuk kemaslahatan keluarga dan rumah tangga, perkawinan hanya boleh dilakukan calon mempelai yang telah mencapai umur yang ditetapkan dalam pasal \& Undang-undang Nomor 1 Tahun 1974 yakni calon suami sekurangkurangnya berumur 19 tahun dan calon istri sekurang-kurangnya berumur 16 tahun. (2) Bagi calon mempelai yang belum mencapai umur 21 tahun harus mendapat izin sebagaimana yang diatur dalam pasal 6 ayat (2), (3), (4) dan (5) Undnag-undang Nomor 1 Tahun 1974.30

Pasal 16 ayat (1) Kompilasi Hukum Islam membahas mengenai persetujuan calon mempelai yang berbunyi: "Perkawinan didasarkan atas persetujuan calon mempelai". ${ }^{31}$ Walaupun didalam Kompilasi Hukum Islam itu merupakan peraturan yang di ambil dari aturan fiqh dan di dalam hukum Islam tidak melarang terjadinya pernikahan di bawah umur 19 tahun

${ }^{29}$ Lihat Pasal 14 Kompilasi Hukum Islam: "Untuk melaksanakan perkawinan harus ada: a. Calon suami; b. Calon Isteri; c. Wali nikah; d. Dua orang saksi dan; e. Ijab dan Kabul”

30 Kompilasi Hukum Islam

31 Ibid., 
bagi pria dan 16 tahun bagi wanita. ${ }^{32}$ Karena tentang batas usia pernikahan tidak dibicarakan dalam kitab-kitab fiqh. ${ }^{33}$

Ketentuan batas umur ini, seperti disebutkan dalam Kompilasi Hukum Islam Pasal 15 ayat (1) didasarkan kepada pertimbangan kemaslahatan keluarga dan rumah tangga pernikahan. Hal itu sejalan dengan prinsip yang diletakkan Undang-undang Perkawinan, bahwa calon suami istri itu harus telah matang jiwa raganya untuk dapat melangsungkan pernikahan, agar supaya dapat mewujudkan tujuan pernikahan secara baik tanpa berakhir pada perceraian dan mendapat keturunan yang baik dan sehat. Untuk itu harus dicegah adanya pernikahan antara calon suami istri yang masih dibawah umur. ${ }^{34}$

Di dalam Kompilasi Hukum Islam mengatur secara spesifik mengenai batasan umur untuk melangsungkan pernikahan yaitu Pasal 15 ayat (1) tetapi tidak diaturnya mengenai dispensasi nikah. Dispensasi nikah hanya diatur dalam Pasal 7 ayat (2) Undang-undang Perkawinan Nomor 1 Tahun1974. Walaupun tidak diaturnya mengenai dispensasi nikah tetapi Kompilasi mengatur mengenai batasan umur, secara tidak langsung baik pria maupun wanita apabila ingin melaksanakan pernikahan harus memenuhi persyaratan yang telah ditentukan oleh peraturan perundang-undangan yang berlaku di Indonesia, terutama masyarakat yang beragam Islam. ${ }^{35}$

\section{Perkara Dispensasi Nikah di Pengadilan Agama Parigi}

Pengadilan Agama Parigi yang merupakan Pengadilan Tingkat Pertama bertugas dan berwenang memeriksa, memutus, dan menyelesaikan perkara-perkara di tingkat pertama antara orang-orang yang beragama Islam di bidang: perkawinan, waris, wasiat, hibah, wakaf, zakat, infaq, shadaqah

32 Hilman Hadikusuma, Hukum Perkawinan Indonesia, 49.

${ }^{33}$ Amir Syarifuddin, Hukum Perkawinan Islam di Indonesia Antara Fiqh Munakahat dan Undang-Undang Perkawinan (Jakarta: Prenadamedia Group, 2006), 66.

34 Sudarsono, Hukum Perkawinan Nasional (Jakarta: PT Rineka Cipta, 2010), 7.

35 Lihat Kompilasi Hukum Islam, Buku I Hukum Perkawinan, Pasal 15 ayat (2):"Bagi calon mempelai yang belum mencapai umur 21 tahun harus mendapat izin sebagaimana yang diatur dalam pasal 6 ayat (2), (3), (4), dan (5) UU No. 1 Tahun 1974. 
dan ekonomi syariah sebagaimana diatur dalam pasal 49 Undang-Undang Nomor 3 Tahun 2006 tentang Perubahan atas Undang-Undang Nomor 7 Tahun 1989 tentang Peradilan Agama.

1. Tatacara dan Proses Penerimaan Perkara Dispensasi Nikah di Pengadilan Agama Parigi

Syarat-syarat dalam pengajuan dispensasi:

i. Surat penolakan dari Kantor Urusan Agama (KUA) yang berisi alasanalasan mengapa ditolak dari KUA.

ii. Surat keterangan pemberitahuan adanya halangan / kurangnya persyaratan nikah dari Kantor Urusan Agama.

iii. Satu lembar foto copy KTP Pemohonan calon (suami istri) yang dimateraikan Rp.6000.

iv. Foto copy Kartu Keluarga pemohon di materaikan Rp. 6000.

v. Satu lembar foto copy akta nikah duplikat kutipan akta nikah pemohon yang dimateraikan Rp. 6000 dan menunjukan yang asli.

vi. Satu lembar foto copy akta kelahiran calon suami yang dimateraikan Rp. 6000 .

vii. Satu lembar foto copy akta kelahiran calon istri yang dimateraikan Rp. 6000 .

viii. Satu lembar foto copy akta nikah orang tua calon dimateraikan Rp. 6000.

ix. Surat keterangan kehamilan dari dokter /Bidan (bagi yang hamil).

X. Surat keterangan status dari Kelurahan / Desa

xi. Membayar biaya panjar.

Proses dan Tahap Pengajuan dispensasi

i. Proses pengajuan dispensasi

a) Pengadilan Agama Parigi akan menerima setiap permohonan yang akan diajukan oleh orang tua anak baik secara lisan maupun tertulis.

b) Pengadilan Agama Parigi akan memberikan penjelasan mengenai kebijakan dan prosedur pada saat masyarakat mengajukan permohonan. 
c) Pengadilan Agama Parigi akan memberikan tanda terima, jika pengajuan diajukan secara tertulis maupun lisan, bila pengajuanya dengan lisan maka akan dibantu oleh pertugas dalam pengajuan

d) Pengadilan Agama Parigi hanya akan menindak lanjuti pengajuan yang mencantumkan idenititas.

e) Masyarakat yang mengajukan sedapat mungkin menyantumkan identitas dan mengirimkan atau menyertakan berkas yang dapat menguatkan permohonan tersebut. Namun demikian selama informasi dalam pengajuan benar dan memiliki dasar yang kuat, pengajuan tersebut akan tetap di tindak lanjuti walaupun tidak mencantumkan identitas.

f) Setiap data dan identitas yang diberikan akan dirahasiakan

g) Mendapatkan surat kuasa untuk membayar

h) Membayar uang panjar biaya perkara

i) Perkara disidangkan

j) Proses persidangan

k) Sidang diputus hakim

ii. Tahap Persiapan

a) Sub Kepaniteraan permohonan gugatan mempelajari kelengkapan dan mencatat semua data-data perkara yang baru di terimanya dalam buku penerimaan tentang perkara, kemudian menyampaikannya kepada panitera dengan melampirkan semua formulir formulir yang berhubungan dengan pemeriksaaan perkara.

b) Panitera sebelum meneruskan berkas perkara yang baru diterimanya itu kepada ketua pengadilan agama, terlebih dahulu meminta pertugas yang bersangkutan untuk mencatatnya dalam buku register perkara.

c) Selambat-lambatnya pada hari kedua setelah surat-surat permohon diterima dibagian kepaniteraan, panitera harus menyerahkan kepada ketua pengadilan agama yang selanjutnya ketua pengadilan agama mencatat dalam buku ekspedisi yang ada padanya dan mempelajarinya, kemudian menyampaikan kembali berkas-berkas perkara tersebut 
kepada panitera dengan disertai penetapan / penunjukan majelis hakim / hakim yang sudah harus dilakukan dalam waktu sepuluh (10) hari sejak gugatan / permohonan di daftarkan.

d) Panitera menyerahkan berkas perkara yang diterimanya kepada ketua / wakil etua pengadilan selanjutnya ketua pengadilan agama akan menunjuk hakim dan melimpahkan perkara kepada majelis hakim yang bersangkutan untuk disidangkan dan diputus.

e) Paniteria menunjuk seorang atau lebih paniteria penganti untuk perbantuan pada majelis hakim yang bersangkutan.

iii. Proses Penerimaan Perkara Dispensasi Nikah

a) Orang tua anak yang ingin mengajukan permohonan, terlebih dahulu mendaftar ke meja satu. oleh meja satu di terima surat permohonan, lalu ditaksir biaya perkara kemudian dibuat SKUM.

b) Setelah Menerima Surat Kuasa Untuk Membayar (SKUM) Pemohon datang ke kasir untuk membayar biaya panjar perkara, pertugas kasir menerima dan menandatangani SKUM lalu memberi nomor pada SKUM dan tanda lunas.

c) Pertugas di meja satu mendaftar permohonan lalu memberi nomor perkara sesuai nomor SKUM, setelah itu berkas perkara diserahkan pada ketua Pengadilan Agama melalui paniteria/wakilnya

d) Berkas perkara yang telah diterima ketua Pengadilan Agama untuk dipelajari, kemudian Ketua Pengadilan Agama membuat Majelis Hakim.

e) Paniteria membuat penetapan paniteria pengganti dan menyerahkan berkas pada majelis hakim.

f) Majelis Hakim yang ditunjuk untuk memeriksa dan mengadili perkara menentukan hari sidang, kemudian memerintahkan pada juru sita untuk memanggil pihak pihak yang berperkara, setelah itu majelis hakim memeriksa dan memutuskan perkara. 
g) Setelah perkara di putus oleh Majelis Hakim, Meja Tiga menerima berkas perkara yang telah diminut oleh pengadilan, memberikan putusan pada para pihak yang tidak hadir lewat juru sita.

2 Latar Belakang Permohonan Dispensasi Nikah di Pengadilan Agama Parigi

Terdapat banyak faktor yang menjadi alasan diajukannya permohonan dispensasi nikah di Pengadilan Agama Parigi, salah satu faktor yang mendominasi adalah kehamilan di luar nikah pada pasangan calon pengantin di bawah umur. Selain kehamilan di luar nikah, terdapat faktorfaktor lain yang menjadi latar belakang permohonan dispensasi nikah di Pengadilan Agama Parigi, seperti kekhawatiran orangtua pada pergaulan anaknya hingga pengaruh adat dan kebiasaan masyarakat sekitar.

Adapun, latar belakang perkara dispensasi nikah pada Pengadilan Agama Parigi Tahun 2017 secara rinci adalah sebagai berikut:

Tabel 1

Latar Belakang Perkara Dispensasi Nikah Pa Parigi 2017

\begin{tabular}{|c|c|c|c|}
\hline NO & Latar Belakang & $\begin{array}{l}\text { Jumlah } \\
\text { Perkara }\end{array}$ & Nomor Perkara \\
\hline 1 & Hamil & 15 & $\begin{array}{l}\text { Nomor } 2 / \text { Pdt.P/2017/PA.Prgi } \\
\text { Nomor 4/Pdt.P/2017/PA.Prgi } \\
\text { Nomor 5/Pdt.P/2017/PA.Prgi } \\
\text { Nomor 6/Pdt.P/2017/PA.Prgi } \\
\text { Nomor 12/Pdt.P/2017/PA.Prgi } \\
\text { Nomor 13/Pdt.P/2017/PA.Prgi } \\
\text { Nomor 14/Pdt.P/2017/PA.Prgi } \\
\text { Nomor 16/Pdt.P/2017/PA.Prgi } \\
\text { Nomor 41/Pdt.P/2017/PA.Prgi } \\
\text { Nomor 46/Pdt.P/2017/PA.Prgi } \\
\text { Nomor 50/Pdt.P/2017/PA.Prgi } \\
\text { Nomor 51/Pdt.P/2017/PA.Prgi } \\
\text { Nomor 62/Pdt.P/2017/PA.Prgi }\end{array}$ \\
\hline
\end{tabular}




\begin{tabular}{|c|c|c|c|}
\hline & & & $\begin{array}{l}\text { Nomor } \\
\text { 217/Pdt.P/2017/PA.Prgi } \\
\text { Nomor } \\
\text { 221/Pdt.P/2017/PA.Prgi }\end{array}$ \\
\hline 2 & Menghindari zina & 7 & $\begin{array}{l}\text { Nomor 1/Pdt.P/2017/PA.Prgi } \\
\text { Nomor 8/Pdt.P/2017/PA.Prgi } \\
\text { Nomor 10/Pdt.P/2017/PA.Prgi } \\
\text { Nomor 11/Pdt.P/2017/PA.Prgi } \\
\text { Nomor 15/Pdt.P/2017/PA.Prgi } \\
\text { Nomor 59/Pdt.P/2017/PA.Prgi } \\
\text { Nomor 61/Pdt.P/2017/PA.Prgi }\end{array}$ \\
\hline 3 & Dijodohkan & 1 & Nomor 40/Pdt.P/2017/PA.Prgi \\
\hline 4 & $\begin{array}{l}\text { Telah menikah/belum } \\
\text { ada buku nikah }\end{array}$ & 1 & Nomor 22/Pdt.P/2017/PA.Prgi \\
\hline & TOTAL PERKARA & 24 & \\
\hline
\end{tabular}

Sumber : data Pengadilan Agama Parigi

Dari tabel tersebut diketahui bahwa permohonan dispensasi nikah di Pengadilan Agama Parigi Tahun 2017 memiliki beberapa latar belakang yang beragam, di antaranya karena hamil di luar nikah, untuk menghindari perbuatan zina, dijodohkan oleh keluarga, hingga ada yang telah menikah di bawah umur namun belum tercatat di Kantor Urusan Agama sehingga mengajukan dispensasi kepada pihak pengadilan.

3. Pertimbangan Hakim Terhadap Dispensasi Nikah di Bawah Umur pada Pengadilan Agama Parigi

Dalam proses persidangan perkara dispensasi nikah di Pengadilan Agama Parigi, majelis hakim terlebih dahulu membacakan permohonan yang dibuat oleh para pihak pemohon untuk memperjelas latar belakang diajukannya permohonan dispensasi nikah tersebut. Selanjutnya, majelis hakim mendengarkan keterangan dari para pemohon, dan melakukan negosiasi demi menghasilkan putusan yang bijaksana. Selain para pemohon, 
majelis hakim juga mendengarkan keterangan dari anak pemohon (calon pengantin), serta dua orang saksi. Adapun dua orang saksi yang dihadirkan, merupakan saudara, keluarga, atau tetangga yang dekat hubungannya dengan calon pengantin juga pemohon.

Dalam memutuskan perkara dispensasi nikah, selain mempertimbangkan aspek yuridis normatif, majelis hakim juga mempertimbangkan apakah dispensasi nikah bagi kedua calon pengantian di bawah umur tersebut bisa memberi manfaat yang lebih besar atau justru berpotensi menimbulkan mudharat bagi masa depannya

Adapun alasan-alasan dasar dikabulkannya permohonan dispensasi nikah di Pengadilan Agama Parigi sebagai berikut:

a. Mengindari kemudharatan akibat hamil di luar nikah

Berdasarkan hasil wawancara mengenai dispensasi nikah di Pengadilan Agama Parigi, diperoleh keterangan bahwa salah satu alasan terbesar pengajuan permohonan dispensasi nikah karena calon pengantin perempuan telah hamil di luar nikah, yaitu sebanyak 62,5\% dari total 24 perkara permohonan dispensasi nikah di Pengadilan Agama Parigi tahun 2017. Dalam memutus perkara dispensasi nikah karena hamil di luar nikah, selain mempertimbangkan aspek normatif, majelis hakim juga mempertimbangkan apakah dispensasi nikah tersebut bisa memberi manfaat yang lebih besar atau justru berpotensi menimbulkan mudharat bagi masa depan anak. Menimbang bahwa pemberian dispensasi nikah kepada kedua calon pengantin adalah demi kepentingan terbaik bagi keduanya dan untuk melindungi anak tersebut, karena menikah adalah gharizah insaniyah (naluri kemanusiaan) yang harus dipenuhi dengan jalan yang sah agar tidak mencari jalan yang sesat atau jalan yang menjerumukan ke dalam perbuatan zina.

b. Hubungan yang erat oleh kedua anak

Faktor kedua yang menjadi pertimbangan majelis hakim dalam memutus perkara dispensasi nikah di Pengadilan Agama Parigi adalah karena kedua calon pengantin sudah berpacaran lama dan memiliki 
hubungan yang amat erat. Mempertimbangkan bahwa calon pengantin telah memberikan keterangan di muka persidangan yang pada intinya keduanya sudah berpacaran dan sudah siap untuk menikah, tidak ada paksaan untuk menikah dan calon pengantin laki-laki sudah siap menjadi suami dan kepala rumah tangga. Serta antara calon pengantin laki-laki dan calon pengantin perempuan juga tidak mempunyai hubungan keluarga, baik secara nasab, semenda ataupun sesusuan.

c. Telah melakukan persiapan pernikahan

Dalam memutuskan perkara dispensasi nikah, para hakim Pengadilan Agama Parigi cenderung tidak kaku dan melakukan pertimbangan yang matang dari berbagai sisi. Dalam setiap perkara dispensasi nikah yang diterima oleh pengadilan, majelis hakim menggunakan prinsip maslahah mursalah dan senantiasa menghindari mudharat yang akan diperoleh berbagai pihak. Maka pertimbangan-pertimbangan umum seperti halnya persiapan pernikahan yang sudah dilakukan oleh calon pasangan yang ditolak pernikahannya oleh Kantor Urusan Agama setempat hingga beban moril yang akan ditanggung keluarga dan calon pasangan jika permohonan tersebut tidak dikabulkan oleh pengadilan tetap diperhitungkan.

d. Telah baligh menurut Islam

Berdasarkan fakta-fakta hukum dalam perkara dispensasi nikah, majelis hakim berkesimpulan bahwa calon pengantin laki-laki telah baligh raganya, terbukti dari tanda-tanda fisik bahwa ia sudah baligh, calon pengantin laki-laki juga telah memenuhi kategori baligh jiwanya, terbukti dengan pernyataannya bahwa ia sudah siap menjadi suami bagi istrinya dan kelak menjadi bapak bagi anaknya. Meskipun dilihat dari usia anak para Pemohon tersebut masih di bawah usia yang diperkenankan melangsungkan perkawinan menurut Pasal 7 ayat (1) Undang-Undang Nomor 1 Tahun 1974, namun dari fakta yang terungkap dipersidangan telah diketahui bahwa dari segi fisik maupun mentalnya dipandang telah cukup mampu dan layak untuk menjalankan kewajibannya sebagai seorang suami. Dalam persidangan 
majelis hakim telah memberikan penjelasan kepada calon pengantin perempuan tentang akibat-akibat yang akan timbul setelah terjadinya perkawinan seperti adanya tanggung jawab seorang istri melayani suaminya dan sebagi ibu yang nantinya harus mendidik anaknya dan mengurusi segala urusan rumah tangga. dari penjelasan tersebut calon pengantin perempuan yang masih di bawah umur menyatakan kesanggupannya di depan mejelis hakim atas akibat-akibat yang akan timbul setelah terjadinya perkawinan tersebut.

Hakim juga sewaktu-waktu dapat menolak untuk mengabulkan permohonan tersebut jika terdapat alasan yang kuat. Salah satu contohnya adalah ketika calon pasangan di bawah umur merasa terpaksa dan tidak ridha terhadap penikahan yang diajukan para pemohon. Selain itu, majelis hakim Pengadilan Agama Parigi juga dapat memberikan masukan kepada para pemohon berupa alternatif lain jika pernikahan tersebut dinilai belum terlalu mendesak untuk dilangsungkan. Adapun untuk latar belakang permohonan dispensasi nikah di Pengadilan Agama Parigi selain karena hamil di luar nikah dan tidak ada hal yang mendesak, maka majelis hakim dapat memberikan saran dan melakukan negosisasi kepada para pemohon.

\section{Analisis Kepastian Hukum, Keadilan dan Kemanfaatan}

Berdasarkan hasil penelitian, diperoleh kesimpulan bahwa pertimbangan hakim dalam menangani perkara dispensasi nikah di Pengadilan Agama Parigi mengkonfirmasi teori Gustav Radbruch yang menyatakan tujuan hukum ada tiga hal, yaitu kepastian hukum, keadilan hukum, dan kemanfaatan hukum. Adapun penjabaran secara lengkap adalah sebagai berikut:

\section{Kepastian hukum}

Sebagaimana yang tercantum pada Pasal 2 ayat (2) Undang-Undang Perkawinan Nomor 1 Tahun 1974, bahwa setiap perkawinan harus dicatat sesuai dengan peraturan perundang-undangan yang berlaku. UndangUndang Perkawinan juga menjelaskan batasan usia perkawinan bagi laki-laki 
dan perempuan, serta upaya yang dapat ditempuh apabila terjadi penyimpangan atas usia yang telah ditetapkan. Dalam Pasal 7 ayat (2) Undang-Undang Perkawinan menyebutkan bahwa penyimpangan terhadap usia perkawinan berdasarkan ketentuan perundang-undangan, dapat meminta dispensasi kepada Pengadilan yang diminta oleh kedua orang tua pihak laki-laki atau perempuan sebagai Pemohon.

2. Keadilan

Dalam perkara dispensasi nikah, faktor penyebab diajukannya permohonan kebanyakan terjadi karena kehamilan yang terjadi pada anak usia dini sebelum adanya ikatan perkawinan yang sah. Hal tersebut kemudian menjadi hal yang dianggap sangat memalukan bagi orang tua dan keluarganya di kalangan masyarakat.

Dalam hal ini, orang tua dan keluarga merasa perlu untuk mendaftarkan pernikahan anaknya agar sah secara agama dan hukum, dengan mematuhi aturan-aturan pernikahan yang berlaku. Adapun Kantor Urusan Agama setempat kemudian menolak mencatat pernikahan tersebut dengan alasan kedua atau salah satu dari calon pengantin merupakan anak di bawah umur yang usianya belum mencukupi batas umur pernikahan yang tercantum dalam Undang-Undang Pernikahan Nomor 1 Tahun 1974, maka orang tua ataupun pihak keluarga melakukan inisiatif untuk mengajukan permohonan dispensasi nikah di pengadilan agama.

Hakim Pengadilan Agama Parigi menilai orang tua yang mengajukan permohonan dispensasi nikah di pengadilan untuk anaknya, merupakan individu yang sadar hukum. Mereka memilih untuk melakukan upaya hukum agar pernikahan anaknya sah di mata agama dan negara daripada menikahkan anaknya secara siri atau pernikahan yang sah secara agama saja tanpa disertai dengan pencatatan di Kantor Urusan Agama.

Aspek kesadaran hukum dari orang tua ini layak dihargai dan dijadikan bahan pertimbangan yang cukup kuat untuk mengabulkan permohonan dispensasi nikah di Pengadilan Agama Parigi. Dalam hal ini, 
majelis hakim memilih berlaku adil kepada orang tua yang rela datang ke Pengadilan Agama dan mengorbankan waktu serta biaya untuk mengajukan permohonan dispensasi nikah.

Terlebih, pernikahan bagi umat muslim merupakan hal asasi yang mengandung nilai ibadah dan oleh karenanya, hak tersebut harus diberikan kepada yang memerlukannya demi menegakkan sunnah Rasulullah, bahkan Allah swt. memerintahkan setiap insan untuk menikah yang dengannya diharapkan kehidupan sepasang suami istri itu kelak menjadi pasangan yang saling menopang dan saling memberi bantuan lahir batin antara satu sama lain hingga akhirnya kehidupan mereka menjadi berkecukupan dan berkemampuan dalam berbagai aspeknya.

\section{Kemanfaatan}

Dalam perkara dispensasi nikah yang mendesak dan sangat dibutuhkan, dapat memberikan manfaat bagi Pemohon dan calon suami istri. Seperti penjelasan tentang berbagai faktor yang menjadi penyebab diajukannya permohonan dispensasi nikah di Pengadilan Agama Parigi, maka dapat kita ketahui bahwa alasan orang tua sebagai pihak Pemohon adalah karena kondisi yang sudah mendesak.

Dalam hal ini, peran hukum dibutuhkan oleh Pemohon dalam memberikan kemudahan dan jalan keluar atas persoalan-persoalan yang dihadapi Pemohon. Apabila permohonan dispensasi nikah tersebut tidak dikabulkan tentunya akan menimbulkan dampak yang sangat besar.

Seperti dalam kasus kehamilan di luar nikah pada anak yang usianya masih di bawah umur dari ketentuan Undang-Undang Perkawinan untuk melangsungkan pernikahan, maka sang anak serta keluarganya akan mendapat tekanan dari masyarakat berupa gunjingan dan pengucilan karena dianggap tidak mampu mendidik anak-anaknya dengan baik. Meskipun aib yang sudah terlanjur dilakukan tidak dapat dihapus di mata masyarakat, namun yang lebih penting adalah upaya hukum yang dilakukan oleh orang 
tua akan membuat hubungan anak-anaknya lebih jelas dan sah di mata hukum.

Dengan keabsahan status perkawinan di mata hukum, maka kepastian status bayi yang nantinya akan dilahirkan oleh calon pengantin perempuan yang telah hamil terlebih dahulu sebelum melakukan perkawinan tersebut, juga akan jelas. Hal ini menjadi sangat penting bagi kehidupan bayi yang akan dilahirkan nantinya. Jika permohonan dispensasi nikah tidak dikabulkan, maka akan menimbulkan mudharat bagi calon bayi yang akan dilahirkan.

\section{Penutup}

Berdasarkan hasil penelitian yang telah dilakukan oleh Penulis, maka diperoleh hasil sebagai berikut:

1. Faktor-faktor yang menjadi latar belakang permohonan dispensasi nikah di Pengadilan Agama Parigi diantaranya yaitu: telah terjadi kehamilan di luar nikah, dijodohkan oleh kedua pihak keluarga, untuk menghindari zina akibat menjalin hubungan yang sangat dekat, serta ingin menerbitkan buku nikah setelah sebelumnya sudah menikah di usia muda.

2. Adapun pertimbangan hakim dalam memutuskan perkara dispensasi nikah di Pengadilan Agama Parigi adalah sebagai berikut, yaitu : menolak kemudharatan akibat kehamilan di luar nikah, mencegah akibat buruk lain yang akan timbul, hubungan yang erat antara kedua keluarga, persiapan pernikahan yang telah dilakukan, sang anak sudah baligh menurut Islam, serta kepatuhan keluarga terhadap prosedur hukum. 


\section{DAFTAR PUSTAKA}

Anshary, Hukum Perkawinan di Indonesia,Yogyakarta: Pustaka Pelajar, 2015

Arto, Mukti, Praktek Perkara Perdata Pada Pengadilan Agama, Yogyakarta: Pustaka Pelajar, 2007

Asyhadie, Zaeni dan Arif Rahman, Pengantar Ilmu Hukum, Jakarta: PT Raja Grafindo Persada, 2014

Badan Kependudukan Keluarga Berencana Nasional, Seri Genre: Menyiapkan Generasi Emas, Jakarta: BKKBN, 2013

Direktorat Jendral Pembinaan Kelembagaan Agama Islam, Bahan Penyuluhan Hukum, Jakarta: Departemen Agama RI, 2001

Hadikusuma, Hilman, Hukum Perkawinan Indonesia, Bandung: CV. Mandar Maju, 2007

Iriani, Dewi, Pengetahuan Ilmu Hukum Dan Pengenalan Tentang Hukum di Indonesia, Ponorogo: CV. Senyum Indonesia, 2016

Manan, Abdul, Aneka Masalah Hukum Perdata Islam Di Indonesia, Jakarta: Kencana, 2006

Mertokusumo, Sudikno, Penemuan Hukum, Yogyakarta: Liberty, 2010

Sudarsono, Hukum Perkawinan Nasional, Jakarta: PT Rineka Cipta, 2010

Syarifuddin, Amir, Garis- Garis Besar Fiqih, Jakarta: Prenada Media, 2003

SYarifuddin, Amir, Hukum Perkawinan Islam di Indonesia Antara Fiqh Munakahat dan Undang-undang Perkawinan, Jakarta: Prenadamedia Group, 2006

Yusuf, Psikologi Perkembangan Anak dan Remaja (Bandung: PT Remaja Rosdakarya Offset, 2004 